\title{
ISLAMIC EDUCATION RECONSTRUCTION: MASTERY LEARNING BASED IN MODERN ISLAMIC BOARDING SCHOOL
}

\section{Lila Pangestu Hadiningrum}

\author{
Institut Agama Islam Negeri (IAIN) Surakarta \\ Jl. Pandawa, Puncangan, Kartasura, Sukoharjo, Jawa Tengah \\ Email: lilahadiningrum@gmail.com
}

\begin{abstract}
The growing secularism and radicalism are increasingly widespread in Islamic education system. Efforts to reconstruct the Islamic educational system have been done but results yet to satisfy Muslim society. Comprehensive teaching in Islamic boarding school is expected to be a solution to solve problems relating to moral, role mode, and leadership crisis as well as the commercialization of education. The implementation of mastery learning in modern Islamic boarding school is considered as a breakthrough in improving and implementation of integrated learning and curriculum. Islamic boarding school is expected to become one of role model in Muslim education institutionswhich is able to produce high quality of human resources with high work ethic and morale.
\end{abstract}

Abstrak. Di era modernisasi, berkembangnya paham sekulerisme dan radikalisme dalam dunia pendidikan semakin marak tak terkecuali dalam system pendidikan Islam. Upaya merekonstruk sisistem pendidikan Islam dengan pembelajaran tuntas pada Islamic boarding school sebagai pesantren kekinian diharapkan menjadi solusi dari permasalahan krisis moral, krisis figur, krisis keteladanan, komersialisasi pendidikan serta budaya literasi yang rendah. Penggunaan mastery learning (pembelajaran tuntas) pada Islamic boarding school sebagai pesantren kekinian sebagai terobosan pembenahan dalam pelaksanaan pembelajaran dan kurikulum terpadu. Islamic boarding school diharapkan menjadi salah satu icon learning society yang akan mengembangkan potensi sumber daya manusia dengan etos kerja yang tinggi menuju madani.

Key words:Islamic education, mastery learning, pesantren

DOI: http://dx.doi.org/10.24239/jsi.v14i1.458.1-15 


\section{Introduction}

Education is a system which consist several functional components that interact, dependent, and useful to achieve goals. That components are the objectives of education, educators, students, educational environment, and educational instruments. The five components of education are implemented in teaching and learning process to achieve goals. An individual is considered has been educated if his/her behavior is changed from "not understand" to "understand" which includes aspects of cognitive, affective, and psychomotor.

Learning is a process to prepare human resources and it should referring to the lerningconcept proposed by the UNESCO ${ }^{1}$ commission which includes learning to think, learning to do, learning to be himself, and learning to live together. The most important learning outcome is an individual has ability to develop himself/herself in further. Learning is not just acquiring knowledge, skills, and attitudes but also the process regarding how the knowledge, skills, and attitudes are gained by the students. $^{2}$

Changes in social value and life pattern were caused by the development of science and technology. In addition, globalization requires the ability of human beings to participate and adapt to the situation. Currently, society live in a high competition environment which requires humans to continuously pursue the quality and excellency of skill and knowledge. ${ }^{3}$ Modern society demands critical, flexible, open, innovative, dexterity, competitive, problem-sensitive, well informed individuals who

\footnotetext{
${ }^{1}$ H.A.R. Tilaar, Beberapa Agenda Reformasi Pendidikan Nasional (Jakarta: Tuan Indonesia, 1999). 61

${ }^{2}$ Semiawan Conny, et. al., Pendidikan Tinggi: Peningkatan Kemampuan Manusia Sepanjang Hayat Seoptimal Mungkin (Jakarta: Dirjen Dikti Depdikbud, 1998). 13

${ }^{3}$ Tilaar, Beberapa Agenda Reformasi Pendidikan Nasional. 53
} 
are able to work in cross-team work, and adapt to change. ${ }^{4}$ Shaffer, 2000 in Hosnan, 2013: ${ }^{5}$ in Global Agenda for Children on "learning for 21 century" states that : "In order to survive the world and create prosperity century, people need to learn more and learn different subjects. A student who live the new century will likely need to gain more knowledge and skills than previous generation ". This shows that 21st century require society to learn more. We must also practice leraning with different approaches or ways because we are facing different times.

Islamic education system prioritizes its philosophy and principles based on the basic Islamic values contained in the Qur'an and Al Hadith. Islamic education seeks the formation of noble character, preparing humans to be ready to life in the world and the hereafter, scientific study, and preparation of professionalism. Islamic education is also an education system based on the core values of Islam. The goals include cognitive, affective and psychomotor abilities. Students should not only know and understand about Islam, but they also must be able to play a role in science and technology development. In addition, students must have noble moral values and they are able to prepare themselves in this world and hereafter life.

The success of education is not only in aspect of cognitive, but in affective (attitude) and psychomotor aspects (skills). Cognitive ability is related to the ability to think which includes intellectual ability ranging from the ability to remember (memory) until the ability to solve problems. Cognitive abilities include memorization, understanding, application, analysis, synthesis and evaluation. Affective ability relates to feelings, emotions, attitudes that show acceptance or rejection, response,

\footnotetext{
${ }^{4}$ Conny, Pendidikan Tinggi: Peningkatan Kemampuan Manusia Sepanjang Hayat Seoptimal Mungkin. 10

${ }^{5}$ Hosnan, Pendekatan Saintifik dan Kontekstual dalam Pembelajaran Abad 21 (Bogor: Ghalia Indonesia, 2013). 2
} 
value appreciation, and practice something. While psychomotor ability is associated with motoric skills. Educational which focuses on formal education is not appropriate, because the concept of education that is widely defined which includes cognitive, affective and psychomotor. Current understanding of education emphasizes on formal education in the school environment. Consequently, if there is an unconformity or deviation in education, the school is often to be blamed.

Education is a process to develop humans potential, cultural inheritance, and interaction of both. The task of Islamic education is to transmit cultural elements from generation to generation. As the result, the identity of Muslim is preserved from time to time. Currently, number of intellectuals have involved in radicalism, secularism, and pragmatism. Islamic education is considered able to create and develop human skills to meet the needs of society all the times. Globalization and modernization demand Islamic education system should be changed according to the times. Formal education is not able to answer the problem because formal education only explores academic competence, and lack of religion values. Islamic boarding schools (salaf) neither able to answer the challenges of changing times because lack of science and technology subjects. The widespread of boarding school and the commercialization of an integrated Islamic school (it is often labelledwith full day school) have not been fully able to overcome the moral crisis. This is what lies behind the need for the reconstruction of the Islamic education system with learning mastery based on Islamic boarding school with new paradigm.

\section{Islamic Education System}

Islamic education system prioritizes moral education and spirituality through religious teaching materials without ignoring general subjects. Islamic education focus on idealism with the main target is to provide learners with spiritual and 
moral education. The learners study the science and other general subjects as a means to achieve mercy from Allah, not to seek meteriality such as job positions.

Mustafa Rahman ${ }^{6}$ argues that Islamic education is amiedto form humans' noble personality, who arenot only focus studying science and technology, but they also must be able to poses good moral. Meanwhile Abdurrahman ${ }^{7}$ adds that the core meaning of Islamic education also focus on comprehensive education to achieve sa'adatuddarain, which is the happiness in the hereafter and material and religious-spiritual balance. One of the basic teachings of the Prophet is total intellectualization, namely the process of humans awareness in various dimensions such as mau'idhahhasanah, wisdom and excellent argumentation.

The essence Islamic education is a continuous process and a lifelong learning process which focus on dynamic learners. Some of Islamic education goals are to form noble character, prepare the life of the world and the hereafter, cultivate the spirit, work ethic, and prepare professionals workers to benefit society.

Some efforts have been done to revitalize Islamic education. This requires Muslim society to reconstruct and reformulate the concept of Islamic education in accordance with the the development of technology and modern sciences. Islamic education should become as agent of change and social transformation which accommodates local culture toward development of learning comunity through meaningful learning. It is importance to consider a new paradigm in Islamic education system to prepare young generation as khalifatullah. Extinction of important Muslim figure, the "kiai", Islamic worldguradians, and the poor role model in Muslim society is caused by the

\footnotetext{
${ }^{6}$ Mustafa Rahman, Paradigma Pendidikan Islam (Yogyakarta: Pustaka Pelajar, 2010). 670

${ }^{7}$ Abdurrahman Mas'ud, Menuju Paradigma Islam Humanis (Yogyakarta: Gama Media, 2003). 183
} 
commercialization and secularization of the formal education system. Low learning culture and lack willingness to understand Islam has resulted in lack creativity to study original Islamic books to preserve Islamic intellectual heritage. Students prefer to read translated books rather than reviewing the original book (the treasures of classical books) that lead to intellectual disparities.

Pesantren as one of Islamic educational institutions support the success of Muslim human resources and culture to minimize the impact western culture influence such as; internetization, westernization, hedonism, gadgets, pragmatism and other values which are in accordance with Islamic values. Islamic boarding school (Pesantren)educational cultural includecreating role model and literacy culture (iqro '). Islamic boarding school education focuses on long-life education which is in according to the teachings of the Prophet. Pesantren with complete and meaningful learning not only develop and produce alumni who are experts in religion but also empower the society. If the salaf (traditional) pesantrenfocuses on the science of religion, modern pesantreneducatonal culture goes hand in hand with the needs of modern society based on Islamic values. The superiority of general sciences (such as; mathematics, science and others) is used to enrich the treasures of humans thought. Meanwhile, Arabic and English competency serve instruments to access to the development of the world and to anticipate changes in modern society.

The role of Islamic educational institutions must be able to answer the challenges of the modern times. The responsibility of pesantren as agent of change becomes the main motivator in reforming pesantreneducational system and its environment to become Islamic boarding schoolswith modern learning mastery strategy. 


\section{Islamic Education Objectives}

To produce superior human resources who have good capability, skill, attitude, and psychological aspects requires long process of education. The quality of the skills, abilities, attitudes, and psychological aspects are determined by the quality learning process. High quality of learning is determined by the system used, while the system used, the process, and the quality of learning is influenced by the charahteristicsof the people involved in the system and process. The need for good education is increasingly in order to improve the quality of the nation, developing character, providing excellence and creative ability. Improving the quality of education can not be separated from the construction of educational goals.

In formulating the objectives of Islamic education, M. Arifin suggests to consider the following issues:

- Goals of human beings related to the life in this wold and hereafter.

- Basic human traits.

- The demands of society and the dynamics civilization.

- The dimensions of ideal life in Islam. In this case, there are at least 3 types of ideal dimensions of Islam; it contain values that seek to improve the welfare of human life on earth, values that encourage humans to achieve a good life, and values that can combine the interests of the world and the hereafter (fí al-dunyā hasanah wa fí al-ākhirat alhasanah). ${ }^{8}$

From the discussion above, it concluded that the purpose of Islamic education is to prepare life in the world and in the hereafter which is reflected in the development of the nature of learners to be aperfect human being (khalifah fī al-ard). The conception indicates that Islamic education must be able to

${ }^{8}$ M. Arifin, Kapita Selekta Pendidikan (Islam dan Umum) (Jakarta: Bumi Aksara, 1993). 120 
develop a good life reality concerning Muslim individual, society, and the universe (horizontal dimension). Islamic education should also be functioned as a tool or a bridge to glorify or achieve eternal relationship with the God.

Islamic education system has components which include: educators, learners, and curriculum. Education has a very decisive role in individualsdevelopment in particular to improve human resources. Indonesia needs educational personnel including creative teachers who are able to make meaningful contributions to science, technology, culture, and artfor the welfare of the nation. Therefore education should be focused on the development of teaching staff to meet the needs of the community and the state. The task of the educator is to plan, implement, and conducting the assessment of teaching and learning. Educators also educate learners to perfect personalities (insān kāmil) in line with the purpose of the God creation. Furthermore, an educator should play a role as a leader who leads the learner, supervise, and organize the learning programs.

Education views learners as the creatures of God who have physical and spiritual nature but they haven't reached the level of maturity in thinking and attitudes. This requires the guidance from educators (asatiż) to develop their potential and maturity. With educators guidance, the learners are expectedto develop ability yo solve problem in their life.

Curriculum is the foundation of education which is used to guide learners in changing their personalities in aspects cognitive, affective, and psychomotoric to be al-insān al-kāmil. The curriculum is also used as a lesson plan which consists systematically arranged competencies of learners. The competencies reflectknowledge and skillswhich can be used to develop their pernonality potentials.

The principles of curriculum in Islamic education include religious principles (referring to the two main sources of Islamic 
shari'ah: Alquran and Sunnah) and its description which includes ijma', qiyās, public interest, good deeds (istihsān), and philosophical principles. Philosophical principles consist of the concept of ontology, epistemology, and axiology unearthed from Muslim thought and in accordance with Islamic teachings. While the principle of psychology consider the development stages and psychological stages of learners, and finally social principles is about creating humans who can take a role in society all the time.

Islamic education curriculum must be improved in order to humanize "humans" (learners) and it is expected learners can their quality according to Islamic values. As a result, the learners can achieve skill development (al-malakah), poses professional skills according market demands (link and match), and fostering good thinking to achieve khalīfah fī al-arḍ.

\section{Learning-Based Mastery at Modern Islamic Boarding School}

Pesantren is a traditional Islamic education institution where students live together and study the religion under the guidance of teachers known as kiai ${ }^{9}$. According to M. Arifin ${ }^{10}$ states the purpose of establishment of boarding school is basically divided into two objectives:

- The special purpose is to prepare the santri (learners) to become religious individual in the religious studies taught by the kiai and practice it in society.

- General goal is to guide students to become human beings who are capable toIslamic mubaliqh(preacher)withistheir surrounding community through science and charity.

In previous era, pesantrenwas a pure private non-formal education institution that does not teach general science. All educational programs were self-composed and generally free of formal requirements. The educational programs consisted of

\footnotetext{
${ }^{9}$ Samsul Nizar, Sejarah Sosial \& Dinamika Intelektual Pendidikan Islam Di Nusantara (Jakarta: Kencana Prenada Media Group, 2013). 91

${ }^{10}$ Arifin, Kapita Selekta Pendidikan (Islam Dan Umum). 248
} 
formal and informal education process which was rununder the supervision of the kiai all the time.

The implementation of education and teaching in pesantren is based on the teachings of Islam with the purpose of worship to get mercy of Allah SWT. Learning time is not limited and asantri is educated to be real believers and have strong personal integrity, independent, and high intellectual qualities. As a result, a santriis expected to be role model in society, disseminate pesantren cultural values with full sincerity, and preaching Islamic teaching. ${ }^{11}$

The principles of education applied in pesantren ${ }^{12}$ are: 1 ) the wisdom, 2) free guided, 3) independent, 4) togetherness, 5) teacher relationships, 6) knowledgeis gained through rationality but it is also dependent on the purity of heart and kiai blessings, 7) Self-organizing ability, 8) Simplicity, 9), Wider Teaching methods, 10) Worship.

In addition, there are several components that can explain the definition of pesantren:

- Pondok: means dormitory where the santri live together and study with the kiai.

- Mosque: (PONDASI) is the ideal place to educate and train the santriin particular related to worship subject and studying holy book as well as other religious knowledge.

- Teaching classical book with several methods such as sorogan, wetonan, delliberation, santri (peer tutoria).

Pesantren received considerable appreciation from the Islamic community. Previously known as originally rural based education institution become an urban educational institution which is known as Islamic boarding school. Pesantren is an

\footnotetext{
${ }^{11}$ Nizar, Sejarah Sosial \& Dinamika Intelektual Pendidikan Islam di Nusantara. 91-92

${ }^{12}$ See Suwensi, Sejarah dan Pemikiran Pendidikan Islam (Jakarta: PT. Raja Grafindo Persada, 2004). 126-127
} 
educational institution that still exis throughout history produce clerics who playactive roles in spreading Islam and transfer of knowledge. Regardless lacking of academic perspectives, pesantren educational system needs to be a refomed in line with the Islamic education policy. It is requires the reconstruction of Islamic education system to be a modern Islamic education institutions.

Learning Mastery as a comprehensive and meaningfull learning mechanism is able to produce boarding school graduates with a mature personality. The development of learning in this modern era leads us to consider the improvement learners ability maximally. This can be done through an effective and efficient teaching strategy in which the learning mastery strategy combined with pesantren culture. Appropriate teaching strategy helps studentsto learn well and to produce good results.Learning mastery based on Islamic boarding school system is an effort to combine a learning system with IQ, EQ, and SQ.

According to Oemar Hamalik ${ }^{13}$ learning msteryis a teaching strategy which use a group-based approach. In other words, learning mastery is a complete learning process that must be achieved by every student through the use cooperative learning approach (group). In context of pesantren, learning mastery refers to learningmeachanism where a learner is taught with ability to work together, learn about the concepts, and reality of life to harmonize with religious knowledge. The role of a teacher (murabbi or asātiż) is very important. Student becomes a teacher partner in learning. The role model and profile ofmurabbi and asatiż figures is an important element in learning mastery. Learning mastery also use a diagnostic approach. The diagnostic approach uses an individual approach, providing services according to individual students orsantri differences. As a result,

\footnotetext{
${ }^{13}$ Oemar Hamalik, Pendekatan Baru Strategi Belajar Mengajar Berdasarkan CBSA (Bandung: Sinar Baru Algesindo, 2001). 85
} 
the learning enables the development of the potential of each student or santrioptimally. Complete learning is an approach which views a studentas an agent that can learn by hims/herself if they get proper learning conditions. Complete learning is a santri effort to achieve comprehensive learning through the teaching materials.

Implementation of mastery learning is carried out through three stages. They are planning, the implementation, and remedial of learning mastery. The planning of mastery learning program is based on the assumption that most santri can learn well, asatid can teach well, and thus, the students will learn well. Implementation of mastery learning is divided into several activities which includes orientation, learning activities, determine the level of mastery of materials, results evaluation, and activities to evaluate the overall programs. The next stage is the implementation of remedial mastery learning. Islamic Boarding School should provide special treatment to students orsantri who have learning difficulties through remedial activities. Brilliant students are given the opportunity to keep their learning speed both religious and general subjects through enrichment activities. Completeness of learning in pesantren is measured from the performance of students in general and religious lessons every week.

The characteristics of mastery learning in pesantren are indicatedin various abilities of santri. Asatids teach subjects through the combination of salaf, quantum, cooperative, active and contextual methods. The avilability of various strategies and methods in mastery learning applies the principle of sustainable progress by allowing students to develop their own potential. Learning mastery is directed at improving the quality of learning through a discipline process.

Mastery Learning in modern Islamic boarding school can be used to balance traditional learning system with modern learning 
system. Modern Islamic boarding schoolswhich apply mastery learning do not only provide Islamic related learning subjects but also provide modern sciences according to the government curriculum. This change does not alter the traditional role of pesantren in Islamic education (tafaqquh $f \bar{i}$ al-dinn) rather it supports the effort to transmit modern science according to the demands of stakeholders. Pesantren is adjusted to the values of progesif and innovative as anticipation strategy to follow the development of science.

Mastery learning in modern Islamic boarding school is an educational institution that has its own characteristics. The characteristics include the availability of education components such as the vision and mission of Islamic boarding school are aligned with the goals, curriculum, teachers (kiai or asātiż), and learning methods. It is expected that pesantren practice the better religious life culture in harmony with the development of science and knowledge. The activities and participation of modern Islamic boarding schoolsin education is aimed to actively take part and build the community throughthe provision of religious knowledge.

\section{Conclusion}

Reconstruction of Islamic education system: mastery learning based on Islamic boarding school as a modern pesantren to respond to the following problems:

Muslim society put high expectation Islamic educational institutions to integrate the general sciences with the religious sciences. This is reflected in the public's expectation of intellectual and professional Muslim graduates in the field of Islamic and other scholarship in accordance with the needs and developments of the global world.

Muslim society has reaised their concern relating phenomena some Muslim who graduate from pesantren posses 
radical and secular thinking. In addition, western culture has also been penetrated Muslim society such as radicalism, secularism, hedonism, westernization, and pragmatism. This has undermined the thinking of Muslims in everyday life.

An integrated educational system (Islamic, Indonesian, and scholarly) is projected to be an alternative way to achieve civil society.

There is a phenomenon of commercialization in Islamic education which more focused on the materiality rather than character buiding. This can be anticipated through integrating the culture of pesantren into the implementation of mastery learning.

Restore the spirit of pesantren in Islamic boarding school through the reinforcement of mastery learning. This can be done through the implementation of integrated curriculum and learning.

The combination of faith, science, and technology can be pursued through modern Islamic boarding school education by combining traditional and modern education systems. In this case the integration of modern and traditional learning method in modern pesantren is not intended to commercialize education but to combine the kekafahan learning according to Islamic values. Reconstruction and modernization of Islamic education is also expected to create an educational institution with true cultural identity.

\section{References}

Arifin, M. Kapita Selekta Pendidikan (Islam dan Umum). Jakarta: Bumi Aksara, 1993.

Conny, Semiawan, et. al. Pendidikan Tinggi: Peningkatan Kemampuan Manusia Sepanjang Hayat Seoptimal Mungkin. Jakarta: Dirjen Dikti Depdikbud, 1998.

Hamalik, Oemar. Pendekatan Baru Strategi Belajar Mengajar Berdasarkan CBSA. Bandung: Sinar Baru Algesindo, 2001. 
Hosnan. Pendekatan Saintifik Dan Kontekstual Dalam Pembelajaran Abad 21. Bogor: Ghalia Indonesia, 2013.

Mas'ud, Abdurrahman. Menuju Paradigma Islam Humanis. Yogyakarta: Gama Media, 2003.

Nizar, Samsul. Sejarah Sosial \& Dinamika Intelektual Pendidikan Islam Di Nusantara. Jakarta: Kencana Prenada Media Group, 2013.

Rahman, Mustafa. Paradigma Pendidikan Islam. Yogyakarta: Pustaka Pelajar, 2010.

Suwensi. Sejarah dan Pemikiran Pendidikan Islam. Jakarta: PT. Raja Grafindo Persada, 2004.

Tilaar, H.A.R. Beberapa Agenda Reformasi Pendidikan Nasional. Jakarta: Tuan Indonesia, 1999. 
Vol. 12, No. 1, Juni 2017: 1-15 